\title{
Effects of Quality and Amounts of Dietary Protein on Dairy Cattle Reproduction and the Environment
}

\author{
Sefa Salo* \\ Department of Animal Science, Wachemo University, Ethiopia
}

Submission: February 02, 2018 ; Published: April 25, 2018

*Corresponding author: Sefa Salo, Department Of Animal Science, Wachemo University, Ethiopia, Email: sefasalon@gmail.com

Abstract

The objective of this paper is to review the effects of quality and amounts of dietary protein on dairy cattle reproduction and the environment. Protein supplementation is one of important nutrient in dairy production. But, an excess amount of protein beyond the requirements of dairy cow affects reproduction as well as the environment. Protein is needed to meet nitrogen requirements of rumen microorganisms as well as used as a direct source of protein for milking cows. An excess amount of rumen degradable protein can be excreted into the environments and impose an impact on it. Excess rumen degradable protein also results in high amounts of ammonia in the blood of dairy cow when there is no sufficient amount of energy to convert ammonia into microbial protein. In addition, conversion of excess ammonia is energy demanding which can result in negative energy balance. This excess ammonia and negative energy balance result in reduced reproductive performance in dairy cows. Therefore, it is important to optimize rumen degradable and rumen undegradable protein content of diets and synchronization of protein with energy is best strategies to overawed ammonia pollution and reproductive problem in the dairy cows.

Keywords: Protein level; Protein quality; Reproduction; Environmental impact; Dairy cattle; Undegradable protein; Dietary protein; Nutrient management; Cattle reproduction; Urease; Faecal N; Ammonia; Luteal phase; Oestrous cycle; Detoxification process; Degradable protein; Methionine; Amino acid

Abbreviations: UDN: Undegradable Dietary Nitrogen; RDN: Rumen Degradable Nitrogen; MUN: Milk Urea Nitrogen; NEB: Negative Energy Balance; AA: Amino Acid

\section{Introduction}

Protein is an important limiting nutrient in ruminants [1]. To produce milk, and more importantly, to achieve high yields, and thereby exploiting the whole production potential of cows, high inputs of feed with high protein contents have become a common practice in dairy farming $[2,3]$. However, many studies have shown that high inclusion of protein in the diets of dairy cows leads to a decreased nitrogen $(\mathrm{N})$ efficiency (the ratio between $\mathrm{N}$ content in the diet and $\mathrm{N}$ in produced milk) and increased excretion of $\mathrm{N}$ via urine and milk [4-6]. A significant part of the dietary $\mathrm{N}$ is thereby lost, in both environmental and economic terms, leading to decreased production efficiency of dairy systems.

Dietary protein intake is the most important factor determining milk nitrogen efficiency, reduction of urinary nitrogen losses, and consequently, ammonia emissions from dairy cow manure. Feeding cows less protein can dramatically decrease urinary $\mathrm{N}$ excretion and increase the efficiency of $\mathrm{N}$ use. Excess feed $\mathrm{N}$ is deaminated and excreted as urea, an $\mathrm{N}$ waste compound, in urine and milk, while undigested ruminal undegradable protein and metabolic $\mathrm{N}$ (sloughed intestinal cells and hindgut fermentation products) are excreted in the faeces [7]. The route and amount of $\mathrm{N}$ excretion are of primary environmental concern; urinary $\mathrm{N}$ is more volatile than faecal $\mathrm{N}$ and is rapidly converted to ammonia. However, reducing the amount of protein fed can have negative impacts on productivity if the diet is not correctly balanced. Therefore, both nutrient intake and nutrient excretion (nutrient management) must be carefully considered.

High protein diets are frequently fed to cows to increase milk production. However, many studies have reported that increasing the percentage of crude protein in the diet results in reduced fertility $[8,9]$. Other authors have reported effects in some circumstances but not in others $[10,11]$ and some have reported no effect $[12,13]$. The process by which this happens is still unclear, but recent research has shown that cows fed excess protein (more than 10-15\% above requirements) required more services per conception and had longer calving intervals [14]. Therefore, the objective of this paper is to review effects of quality and amounts of dietary protein on dairy cattle reproduction and the environment. 


\section{Effect of Protein on Milk Yield}

Protein is an important limiting nutrient in ruminants [1]. It contains two fractions: rumen degradable nitrogen (RDN) and undegradable dietary nitrogen (UDN). Thus, sufficient supply with RDN and UDN or AA is important to satisfy animal's requirements. Kalscheur [15] reported thatruminal undegradable protein needs to be supplement when microbial protein synthesis alone is insufficient to meet the metabolizable protein requirements in dairy animals especially during early lactation. On supplementation of an increased dietary rumen undegradable protein milk yield was increased [16-19]. Similarly, Marghazani found higher milk yield from $40 \%$ RUP on supplementation of $(30,40,50$ and $60 \%)$ rumen undegradable protein. Garduza-Arias [20] found that the average milk production was not affected by the amount of RUP (30 and 40\%) in the supplement. In the study of Zhai [21] no significant difference in milk yield was observed on supplementation of different levels of RUP (30.8,36.2, and $41.6 \%)$. The higher RDP than requirements of rumen microbes results in wastage of expensive part of a diet and also decreases the RUP for efficient utilisation in the small intestine for more yields [22]. On supplementation of 11.3,10.1, 8.8 and 7.6\% RDP on DM basis and on RUP (7.1\%), there was a loss of production as dietary RDP decreased. The reduction may be due to reduced DMI [15] which is associated with a reduction in energy supply to the animal and lead to the reduction in milk yield. Higher dietary RDP concentrations are proposed to increase ruminal microbial growth and digestion, which leads to an increase in milk yield [23].

\section{Effect of Protein on Milk Composition}

Milk composition is a trait of animal species, which can be altered under normal production systems. Changes in a composition are attributed to the altered genetic makeup and by the dietary modifications. Nutrition has direct impacts on milk composition [24]. On supplementation of RUP (30 and $40 \%$ ) milk fat was not affected by the amount of supplement [20]. Similarly, on supplementation of $11.310 .1,8.8$ and $7.6 \%$ RDP on DM basis and RUP (7.1\%), milk protein yields were not significantly affected. However, milk fat yield decreased linearly from 1.43 to $1.15 \mathrm{~kg} / \mathrm{d}$ as RDP in the diet decreased from 11.3 to $7.6 \%$ of DM. Titi [25] observed no significant difference in milk protein percentage for cow fed 14 and $16 \%$ CP, while milk fat content was higher in $16 \%$ CP. Kanjanapruthipong and Buatong [16] also found significantly higher butter fat, protein, solids-not-fat and total solids from $38.5 \%$ on supplementation of 24.1 and $38.5 \%$ RUP of CP for dairy cows. A major factor is the low transfer efficiency (25 to $30 \%$ ) of dietary protein to milk is accounting for the inability of diet to alter milk protein content [24]. Castillo [26] found supplementation of extra CP $(210 \mathrm{~g} / \mathrm{kg}$ and $290 \mathrm{~g} / \mathrm{kg} \mathrm{DM})$ did not affect milk fat, protein, and lactose yield or composition. Protein degradability also had no significant effect on milk composition. In the study of Zhai [21] no significant difference in milk composition was observed on supplementation of different levels of RUP (30.8,36.2, and $41.6 \%)$.

\section{Ammonia Emissions from Dairy Cattle}

Dietary protein is the most important factor determining milk $\mathrm{N}$ efficiency, urinary $\mathrm{N}$ losses, and consequently, ammonia emissions from dairy cow manure [27]. The main source of nutrient pollution from cattle is excess $\mathrm{N}$ excretion. Ammonia is an important environmental pollutant that impacts the quality of human and animal life [28]. Ammonia emissions from dairy operations are an important source of $\mathrm{N}$ pollution [29]. Ruminants excrete excess dietary $\mathrm{N}$ mainly through urine [30]. Urea, the major form of urinary $\mathrm{N}$ is rapidly converted to ammonia after excretion [31]. Dairy farming is also controlled by various regulations to control emissions into the environment [32]. Thus, decreasing $\mathrm{N}$ excretion from dairy cows will help reduce ammonia pollution by dairy operations.

Ammonia can cause serious environmental problems and health problems in gaseous or particulate phases. Nitrogen excretion in the ruminant animal is basically composed of undegradable protein, endogenous material, a microbial protein that escapes digestion and urinary N. Urea is produced mainly in the liver to eliminate excess ammonia present in the blood. Ammonia in blood is a result of domination of amino acids in animal tissues. In ruminants, ammonia in circulation can also come from microbial degradation of $\mathrm{N}$ compounds [33]. Urea in contact with urease, an enzyme produced by microorganisms found in both faeces and in soil is converted to ammonia and then volatilized. The process of ammonia volatilization occurs by mass transfer from the top layer of the manure slurry to the air surrounding the manure surface. The mass transfer is dependent on temperature and air velocity at the manure top layer [34].

\section{Dietary Protein Level on Nitrogen Excretion in Manure}

Dietary protein intake is the most important factor determining ammonia emissions from dairy cow manure. Overall intake of $\mathrm{N}$ affects the total amount of $\mathrm{N}$ excreted via manure, but the type of carbohydrate and forage provided in the diet have greater impacts on the route (faecal or urinary) of excretion [35]. Dietary protein excess can increase $\mathrm{N}$ excretion in manure, especially in urine, increasing ammonia volatilization. A number of studies have shown that the amount of ammonia produced from cattle manure is correlated with $\mathrm{N}$ intake [36]. Protein in the diet directly affects the amount excreted, as shown in a recent study by Lee [37] where manure from cows consuming a $16.7 \%$ $\mathrm{CP}$ diet had an increased ammonia emission rate, and urinary $\mathrm{N}$ contribution to nitrate- $\mathrm{N}$ was $100 \%$ greater than manure from cows consuming $14.8 \%$ CP diet. Similarly, in the study by Burgos [36] ammonia emissions were measured for cows consuming diets ranging from $15 \%$ to $21 \% \mathrm{CP}$. The results showed that the amount of urea in manure increased linearly with dietary CP and was almost 3 times higher in manure from cows consuming a 
$21 \%$ CP diet when compared to the $15 \%$ CP cows. However, on supplementation of different level of dietary CP $(10.2 \%, 11.9 \%$, and $13.5 \%$ ) faecal excretion of $\mathrm{N}$ was not affected by $\mathrm{CP}$ level [38].

Between 57 and $78 \%$ of urinary $\mathrm{N}$ is in the form of urea (De Boer et al., 2002) which is rapidly converted to ammonia (NH3) during manure collection and storage as compared to faecal $\mathrm{N}$ [31]. Therefore, a sizeable reduction in NH3 emissions would be achieved by decreasing dietary protein considering the relatively rapid rate of NH3 volatilization from urine [39]. James [40] have demonstrated that reducing dietary $\mathrm{N}$ intake by Holstein heifers resulted in decreased $\mathrm{NH} 3$ emissions from their manure. In addition, Frank \& Swensson [41] noticed that manure ammonia emissions from cows fed a 19\% CP diet were three times higher than those fed a $13 \%$ CP diet. Similarly, Burgos \& Jackson $[42,43]$ found that manure ammonia emissions decreased linearly when the CP in the feed was decreased from $18 \%$ to $12 \%$ of DM.

\section{Dietary Protein Level on Nitrogen Excretion in Urine}

The route and amount of $\mathrm{N}$ excretion are of primary environmental concern; urinary $\mathrm{N}$ is more volatile than faecal $\mathrm{N}$ and is rapidly converted to ammonia by ureases present in soil and on pen floors [37]. Excess dietary N (from excess feed $\mathrm{CP}$ as well as AA from cell turnover and enzyme production) is converted to urea, which is a soluble compound that will diffuse into various body fluids, such as blood, milk, and urine. About $80 \%$ of $\mathrm{N}$ consumed in excess of $500 \mathrm{~g} / \mathrm{d}$ is believed to be excreted in urine in dairy cows [44]. Naves et al. confirmed that high urea content had higher nitrogen excretion in faeces $(\mathrm{g} / 100 \mathrm{~g}$ of $\mathrm{N}$ intake) and urine (g N/d and g/100g of N intake). In Zhang [38] study, urinary urea $\mathrm{N}$ excretion was increased with increasing dietary CP on supplementation of 10.2, 11.9 and 13.5\% CP level. Castillo also showed that urinary $\mathrm{N}$ excretion was increased by $74 \mathrm{~g} \mathrm{~N} / \mathrm{d}$ with the increase in dietary CP level from $210 \mathrm{~g} / \mathrm{kg}$ DM to $290 \mathrm{~g} / \mathrm{kg}$ DM. The Urinary N excretion is mostly related to increased degradability of protein in the rumen [45]. Total $\mathrm{N}$ excretion, as well as urinary $\mathrm{N}$ excretion, can be decreased if overall dietary $\mathrm{CP}$ concentration can be reduced. CantalapiedraHijar [46] showed that decreasing dietary CP content from $16.5 \%$ to $12.0 \%$ in Jersey cows in late lactation decreased the urinary $\mathrm{N}$ excretion by more than $50 \%$ and increased the $\mathrm{N}$-efficiency from 26.4 to $31.3 \%$, but this came at the expense of decrease in both milk yield by $2 \mathrm{~kg} /$ day and milk protein yield by $18 \%$. Similarly, Hymøller, et al. [47-49] showed an increased N-efficiency and decreased $\mathrm{N}$ excretion with lowered $\mathrm{CP}$ levels at the expense of decreased milk yields. Cyriac [50] also concluded that feeding less $\operatorname{RDP}(11.3,10.1,8.8$ and $7.6 \%)$ improved apparent $\mathrm{N}$ efficiencies from 27.7 to $38.6 \%$ with a trend for lost milk production. Such improvements in $\mathrm{N}$ efficiency will have positive environmental impacts. An increased N-efficiency is achieved by lowering the $\mathrm{CP}$ level in the diet, ranging from 36.5 to $30.4 \%$ with CP contents of $12-17.2 \%$ whereas at the higher CP levels $(16.5-18.8 \%)$ the $\mathrm{N}$-efficiency ranged from 33.0 to $26.4 \%$. Thus, lower MUN and
UUN concentrations indicate a more efficient $\mathrm{N}$-utilization leading to a higher $\mathrm{N}$-efficiency, which is a higher proportion of dietary $\mathrm{N}$, is converted to $\mathrm{N}$ in the product [51].

However, more moderate decreases in dietary CP levels allows increased $\mathrm{N}$-efficiency and decreased $\mathrm{N}$ excretion without any significant losses on production levels [52]. This might be achieved by decreasing dietary $\mathrm{CP}$ with a simultaneous increase in RUP or starch content. Interestingly, maximum microbial protein yield did not give the optimal N-efficiency, but the optimum was achieved by balancing the dietary protein degradation and microbial protein synthesis [52]. Indeed, Nadeu [53] showed that energy availability from carbohydrates as well as synchronization of protein and carbohydrate metabolisms are important for efficient nitrogen utilization by dairy cows. Reynal \& Broderick [52] suggested that the optimal dietary CP level to be $17.7 \%$ (11.7\% RDP) when striving for an optimal $\mathrm{N}$-efficiency, that is balancing the need for a high profitability of the production system and the need for minimizing the negative environmental effects of excessive $\mathrm{N}$-excretion.

\section{Dietary Protein Level on Reproduction}

The effect of dietary protein on reproduction is complex. Prolonged inadequate protein intake has been reported to reduce reproductive performance. More recently it has been found that reproductive performance may be impaired if a protein is fed in amounts that greatly exceed the cow's requirements. Studies have reported negative associations between high dietary $\mathrm{CP}$ and a range of fertility parameters, many studies have found little or no effect [54]. Excessive protein can have negative effects on reproduction [55]. Overfeeding protein during the breeding season and early gestation, particularly the rumen receive an inadequate supply of energy, may be associated with decreased fertility [9]. This decrease in fertility may result from decreased uterine $\mathrm{pH}$ during the luteal phase of the oestrous cycle in cattle fed high levels of degradable protein. Meza-Herrera [56] reported that high concentrations of pre-conception protein resulted in reduced uterine $\mathrm{pH}$ and reduced fertility rate but did not affect luteal function at 15 days post-insemination. Research result indicated that cows fed excess protein (more than $10-15 \%$ above requirements) required more services per conception and had longer calving intervals [25,57]. Similarly, on supplementation of $15-19 \%$ CP lower conception rate from 65 to $53 \%$ was observed [58]. The negative effects of protein supplementation are associated with an increase in blood urea-N, which affects ovarian follicular and embryo development [59]. On supplementation of two levels CP (14 and 16\%) with different levels of rumen bypass methionine $(0,15$ and $25 \%)$ more services per conception (1.8vs1.5) and longer calving intervals (358 vs 351 ) were observed in cow receiving $16 \%$ CP [25].

\section{Dietary Protein Quality on Reproduction}

While limited studies have directly addressed the influence of the type of dietary protein on fertility parameters, a recent study 
by Waterman et al. [60-62] reported improvements in a range of reproductive traits in cows fed high levels of rumen undegradable protein. On supplementation of two levels of RUP (32.78 and $27.47 \%)$ the shortest postpartum mating $(81.33 \pm 19.83$ vs. $91.83 \pm 31.16$ days), shortest service per conception $(1.17 \pm 0.41$ vs. $1.50 \pm 0.55$ times) and the shortest days to first estrus $(97.33 \pm 41.52$ vs. $142.33 \pm 66.87$ days) was observed in $32.7 \%$ supplemented group [63]. Similarly, on supplementation of 24.1 and $38.5 \%$ RUP of CP for dairy cows higher incidence of cystic ovaries and shorter days to first estrus were observed in dairy cows fed $38.5 \%$ RUP indicated that increasing the level of RUP in the diet can have a beneficial effect on fertility when associated with reduced plasma urea concentrations. In this study higher milk urea nitrogen (MUN) is observed in dairy cows fed 24.1\% CPdue to excess RDP which can affect fertility. Recent data suggest that MUN concentrations above $15.4 \mathrm{mg} / \mathrm{dL}$ may result in a reduced probability of pregnancy success in dairy cows [64]. Studies of Sawa \& Jankowska [65,66] also clearly suggested a deterioration of the reproduction rate in dairy cows with increasing milk urea concentrations. However, Řehák [67] found, the cows with the lowest MU had the longest calving to first service interval.

An increase in RUP may increase the supply of amino acid (AA) for intestinal absorption, which may improve the glucogenic potential of the supplement [60] or contribute an essential AA such as methionine, which can improve ovarian function [68]. Ardalan \& Titi [25,69] also reported that supplementation of rumen bypass methionine can improve reproductive performance of dairy cows. Since AA and peptides from degraded RUP are absorbed in the intestine and is readily available to the ruminant, excess RUP has shown to stimulate the pancreas to increase insulin production [70]. Insulin affects ovarian tissues by enhancing LH receptor synthesis and actions of the pituitary through these receptors. Kane [71] suggested that undegraded protein works to improve reproduction by mediating luteinizing hormone and follicle stimulating hormone production.

Effects of supplementing feedstuffs high in undegradable intake protein (UIP) on reproduction are appearing to be dependent on the energy density of the diet [72]. Research by Kane [71] demonstrated negative effects on reproductive hormones when high $(0.71 \mathrm{lb} / \mathrm{d})$ levels of UIP were supplemented, but not at low $(0.25 \mathrm{lb} / \mathrm{d})$ or moderate $(0.48 \mathrm{lb} / \mathrm{d})$ levels. Heifers fed additional UIP $(0.55 \mathrm{lb} / \mathrm{d})$ during development reached puberty at a later age and heavier weight and fewer were serviced in the first 21 days of the breeding season. Pregnancy rate was not affected [73]. However, on supplementation of RUP (30 and 45\%) the interval from calving to first oestrus and the period to first luteal activity was not different in dual-purpose cow, which may be due to similar MUN. But, the interval from parturition to first normal luteal activity and the percentage of animals with luteal activity tended to be improved in the 45\% RUP treated group. The negative effects of protein supplementation are associated with an increase in blood urea nitrogen (BUN), which affects ovarian follicular and embryo development [59]. According to Hammond [74], increased degradability of dietary protein can lead to increased ruminal ammonia concentrations resulting in increased BUN concentrations. Rajala-Schultz [64] and Sawa [65] stated that monitoring the concentration of urea in cow's milk may enable identification of the causes of health problems in cows which mainly affect fertility (Table 1 ).

Table 1: Reproductive performance in double purpose cows which received two different amounts of rumen undegradable protein.

\begin{tabular}{|c|c|c|c|c|}
\hline & \multicolumn{3}{|c|}{ Treatment } \\
\hline & $\begin{array}{c}\text { 30\% RUP } \\
\text { (N=10) }\end{array}$ & $\begin{array}{c}\text { 45\%RUP } \\
\text { (N=10) }\end{array}$ & SEM & p-value \\
\hline $\begin{array}{c}\text { First oestrous postpartum } \\
\text { (days) }\end{array}$ & 42 & 45 & 18.1 & 0.86 \\
\hline $\begin{array}{c}\text { First normal luteal } \\
\text { activity (days) }\end{array}$ & 99 & 82 & 8.02 & 0.15 \\
\hline $\begin{array}{c}\text { Duration of first normal } \\
\text { luteal phase (days) }\end{array}$ & 12 & 12.8 & 1.28 & 0.72 \\
\hline $\begin{array}{c}\text { Percentage of cows with } \\
\text { luteal activity }\end{array}$ & 10 & 40 & - & 0.14 \\
\hline
\end{tabular}

There is a report, which indicates that feeding excess RDP has a negative effect on fertility and delays the first ovulation or oestrus, reduces the conception rate to first insemination, increases the number of days opens and lowers the overall conception rate [75]. There are several proposed mechanisms for this effect including an exacerbated negative energy balance for cows fed diets high in RDP in comparison to diets high in RUP [76] and proven deleterious effects of both ammonia and urea on both oocyte and embryo development $[77,78]$. An excessive intake of degradable protein and a relative shortage of energy to synthesize bacterial proteins will result in the accumulation of excessive ammonia in the rumen [79], which is absorbed through the ruminal wall and converted into urea in the liver. This detoxification process consumes energy and thus may exacerbate negative energy balance (NEB) in early post-partum [80]. NEB is associated with a high incidence of irregular cycles that can both increase the interval to the first service and reduce conception rates [81]. Similarly, Řehák [67] found that NEB had a greater effect on the length of calving to first service interval. Rochijan [63] suggested that synchronizing the rate of dietary energy and nitrogen release is a possible way to avoid excess blood urea nitrogen and excessively high levels of plasma ammonia, leading to improved reproductive efficiency [82-86].

\section{Conclusion}

Protein supplementation for a dairy cow is common practice to improve reproductive activity and increase milk production in the dairy farm. However, excess supplementation of protein above requirements of cow increase excretion of nitrogen in faeces and urine. This excreted nitrogen can cause environmental pollution in the forms of ammonia. Ammonia is one of cause for global warming now a day. Beyond this, excess protein supplementation mostly in the forms of rumen degradable protein can impair the reproductive function of dairy cows. 
This is mostly related to the availability of energy to convert ammonia into microbial protein. Ammonia conversion is energy demanding and results in negative energy balance in the dairy cow. Additionally, availability of excess ammonia in the blood and milk results in reduced reproductive performance through disturbing reproductive hormones in the dairy cows. Therefore, optimizing protein content of diets and synchronization of protein with energy is best strategies to overawed ammonia pollution and reproductive problem in the dairy cows.

\section{References}

1. Ali CS, Din I, Sharif M, Nisa M, Javaid A, et al. (2009) Supplementation of Ruminally Protected Proteins and Amino Acids: Feed Consumption, Digestion and Performance of Cattle and Sheep. Int J Agric Biol 11: 477482.

2. Eastridge ML (2006) Major advances in applied dairy cattle nutrition. J Dairy Sci 89(4): 1311-1323.

3. Aguilar M, Hanigan MD, Tucker HA, Jones BL, Garbade SK, et al. (2012) Cow and herd variation in milk urea nitrogen concentrations in lactating dairy cattle. J Dairy Sci 95(12): 7261-7268.

4. Colmenero JO, Broderick GA (2006) Effect of dietary crude protein concentration on milk production and nitrogen utilization in lactating dairy cows. J Dairy Sci 89(5): 1704-1712.

5. Huhtanen P, Hristov AN (2009) A meta-analysis of the effects of dietary protein concentration and degradability on milk protein yield and milk $\mathrm{N}$ efficiency in dairy cows. J Dairy Sci 92(7): 3222-3232.

6. Broderick GA, Faciola AP, Armentano LE (2015) Replacing dietary soybean meal with canola meal improves production and efficiency of lactating dairy cows. J Dairy Sci 98(8): 5672-5687.

7. VandeHaar MJ, St-Pierre N (2006) Major advances in nutrition: Relevance to the sustainability of the dairy industry. J Dairy Sci 89(4): 1280-1291.

8. Canfield RW, Sniffen CJ, Butler WR (1990) Effects of excess degradable protein on postpartum reproduction and energybalance in dairy cattle. J Dairy Sci 73(9): 2343-2349.

9. Elrod CC, Butler WR (1993) Reduction of fertility and alteration of uterine $\mathrm{pH}$ in heifers fed excess ruminally degradable protein. J Anim Sci 71(3): 694-701.

10. Kaim M, Folman Y, Neumark H, Kaufmann W (1983) The effect of protein intake and lactation number of post-partum body weight loss and reproductive performance of dairy cows. Animal Science 37(2): 229-235.

11. Bruckental I, Drori D, Kaim M, Lehrer H, Folman Y (1989) Effects of source and level of protein onmilk yield and reproductive performance of high-producing primiparous and multiparous dairycows. Anim Prod 48: 319-329.

12. Howard HJ, Aalseth EP, Adams GD, Bush LJ, Mcnew RW, et al. (1987) Influence of dietary protein on reproductive performance of dairy cows. J Dairy Sci 70 (8): 1563-1571.

13. Carroll DJ, Barton BA, Anderson GW, Smith RD (1988) Influence of protein intake and feeding strategy on reproductive performance of dairy cows. J Dairy Sci 71(12): 3470-3481.

14. Yasothai R (2014) Importance of protein on reproduction in dairy cattle. International Journal of Science Environment and Technology 3(6): 2081-2083.

15. Kalscheur KF, Baldwin RL, Glenn BP, Kohn RA (2006) Milk production of dairy cows fed differing concentrations of rumen-degraded protein. J Dairy Sci 89:249-259.
16. Kanjanapruthipong J, Buatong N (2002) Effects of rumen undegradable protein and minerals proteinate on early lactation performance and ovarian functions of dairy cows in the tropics. Asian-Australas J Anim Sci 15(6).

17. Gulati SK, Garg MR, Scott TW (2005) Rumen protected protein and fat produced from oil seeds and meals by formaldehyde treatment; their role in ruminant production and product quality: a review. Aust J Exp Agr 45: 1189-1203.

18. Garg MR, Sherasia PL, Bahanderi BM, Gulati SK, Scott TW (2007) Milk production efficiency improvement in buffaloes through use of slow ammonia release and protected protein supplement. Ital J Anim Sci 6(2): 1043-1045.

19. Habib G (2009) Nutritional management strategies to improve milk production in buffaloes. Pakistan J Zool Suppl Ser 9: 533- 544.

20. Garduza-Arias G, Garcia-Bojalil CM, Mendoza GD, Sánchez-Torres MT, Suárez ME, et al. (2013) Effect of supplementation with rumen undegradable protein on milk production and ovarian activity in double purpose cows. Journal of Applied Animal Research 41(2): 223228.

21. Zhai SW, Liu JX, Wu YM, Ye JA, Xu YN (2006) Responses of milk urea nitrogen content to dietary crude protein level and degradability in lactating Holstein dairy cows. Czech J Anim Sci 51(12): 518-522.

22. Reynal SM, Broderick GA (2003) Effects of feeding dairy cows protein supplements ofvarying ruminal degradability. J Dairy Sci 86(3): 835843.

23. Brun-Lafleur L, Delaby L, Husson F, Faverdin P (2010) Predicting energy $\mathrm{x}$ protein interaction on milk yield and milkcomposition in dairy cows. J Dairy Sci 93(9): 4128-4143.

24. Tripathi MK (2014) Effect of Nutrition on Production, Composition, Fatty acids and Nutraceutical Properties of Milk. J Adv Dairy Res 2:115.

25. Titi HH, Azzam SI, Alnimer MA (2013) Effect of protected methionine supplementation on milk production and reproduction in first calf heifers. ArchivTierzucht 56(22): 225-236

26. Castillo AR, Kebreab E, Beever DE, Barbi JH, Sutton JD, et al. (2001) The effect of protein supplementation on nitrogen utilization in lactating dairy cows fed grass silage diets. J Anim Sci 79(1): 247-253.

27. Hristov AN, Giallongo F (2014) Feeding protein to dairy cows-what should be our target? Tri-State Dairy Nutrition Conference April 14-16, 2014, Pennsylvania State University. pp. 75-84.

28. NRC (2003) Air Emissions from Animal Feeding Operations: Current Knowledge, Future Needs. The National Academies Press, Washington, DC, USA.

29. Aneja VP, Blunden J, James K, Schlesinger WH, Knighton R, et al. (2008) Ammonia assessment from agriculture: US status and needs. J Environ Qual 37(2):515-520.

30. Wright TC, Moscardini S, Luimes PH, Susmel P, McBride BW (1998) Effects of rumenundegradable protein and feed intake on nitrogen balance and milk protein production in dairy cows. J Dairy Sci 81(3): 784-793.

31. Varel VH, Nienaber JA, Freetly HC (1999) Conservation of nitrogen in cattle feedlot waste with urease inhibitors. J Anim Sci 77(5): 11621168.

32. Powers W (2002) Emerging air quality issues and the impact on animal agriculture: Management and nutritional strategies. In: Timonium MD, In: Proc. Maryland Nutrition Conference.

33. De Peters EJ, Ferguson JD (1992) Non-protein nitrogen and protein distribution in the milk of cows. J Dairy Sci 75(11): 3192-3209.

34. Zhang R, Rumsey T, Fadel JG (2005) Development of an improved process based ammonia emission model for agricultural sources. Lake 
Michigan Air Directors Consortium, Des Plaines: Illinois, USA.

35. Weiss WP, Willett LB, St-Pierre NR, Borger DC, McKelvey TR, et al. (2009) Varying forage type, metabolizable protein concentration, and carbohydrate source affects manure excretion, manure ammonia, and nitrogen metabolism of dairy cows. J Dairy Sci 92(11): 5607-5619.

36. Burgos SA, Embertson NM, Zhao Y, Mitloehner FM, DePeters EJ, et al (2010) Prediction of ammonia emission from dairy cattle manure based on milk urea nitrogen: relation of milk urea nitrogen to ammonia emissions. J Dairy Sci 93(6): 2377-2386.

37. Lee C, Feyereisen GW, Hristov AN, Dell CJ, Kaye J, et al. (2014) Effects of dietary protein concentration on ammonia volatilization, nitrate leaching and plant nitrogen uptake form dairy manure applied to lysimeters. J Environ Qual 43(1): 398-408.

38. Zhang B, Wang C, Liu H, Liu J, Liu H (2017) Effects of dietary protein level on growth performance and nitrogen excretion of dairy heifers. Asian-Australas J Anim Sci 30(3): 386-391.

39. Meisinger JJ, Lefcourt AM, Thompson RB (2001) Construction and validation of small mobile wind tunnels for studying ammonia volatilization. Appl Eng Agric 17(3): 375-381.

40. James T, Meyer D, Esparza E, Depeters EJ, Perez-Monti H (1999) Effects of dietary nitrogen manipulation on ammonia volatilization from manure from Holstein heifers. J Dairy Sci 82(11): 2430-2439.

41. Frank B, Swensson C (2002) Relationship between content of crude protein in rations for dairy cows and milk yield, concentration of urea in milk and ammonia emissions. J Dairy Sci 85(7): 1829-1838.

42. Burgos SA, Marcillac N, Fadel JG, Mitloehner FM, DePeters EJ (2006) Prediction of ammonia emission from dairy cattle manure based on milk urea $\mathrm{N}$ : The relationship of milk urea nitrogen to ammonia emission. J Anim Sci 84(1): 355-356.

43. Jackson WA, DePeters EJ, Fadel JG, Mitloehner FM (2006) Effects of dietary crude protein on ammonia emissions from dairy heifers. J Anim Sci 84(1): 260.

44. Kebreab E, France J, Beever DE, Castillo AR (2001) Nitrogen pollution by dairy cows and its mitigation by dietary manipulation. Nutr Cycl Agroecosys 60(1-2): 275-285.

45. Hristov AN, Etter RP, Ropp JK, Grandeen KL (2004) Effect of dietary crude protein level and degradability on ruminal fermentation and nitrogen utilization in lactating dairy cows. J Anim Sci 82(11): 32193229.

46. Cantalapiedra-Hijar G, Peyraud JL, Lemosquet S, Molina-Alcaide E, Boudra H, et al. (2014) Dietary carbohydrate composition modifies the milk $\mathrm{N}$ efficiency in late lactation cows fed low crude protein diets. Animal 8(2): 275-285.

47. Hymller L, Alstrup L, Larsen MK, Lund P, Weisbjerg MR (2014) Highquality forage can replace concentrate when cows enter the deposition phase without negative consequences for milk production. J dairy sci 97(7): 4433-4443.

48. Spek JW, Bannink A, Gort G, Hendriks WH, Dijkstra J (2013) Interaction between dietary content of protein and sodium chloride on milk urea concentration, urinary urea excretion, renal recycling of urea, and urea transfer to the gastrointestinal tract in dairy cows. J Dairy Sci 96(9): 5734-5745.

49. Korhonen M, Vanhatalo A, Huhtanen P (2002) Effect of protein source on amino acid supply, milk production, and metabolism of plasma nutrients in dairy cows fed pasture silage. J Dairy Sci 85(12): 33363351.

50. Cyriac J (2009) Lowering ruminally degradable protein in lactating dairy cow diets. Dissertation submitted to the faculty of Virginia Polytechnic Institute and State University. pp. 132
51. Räisänen S (2016) Milk production and protein utilization in high producing dairy cows fed a low CP diet based on cereals and roughage only - a full lactation study. A MSc thesis presented to Swedish University of Agricultural Sciences, Uppsala, Sweden.

52. Reynal SM, Broderick GA (2005) Effect of dietary level of rumendegraded protein on production and nitrogen metabolism in lactating dairy cows. J Dairy Sci 88(11): 4045-4064.

53. Nadeau E, Englund JE, Gustafsson AH (2007) Nitrogen efficiency of dairy cows as affected by diet and milk yield. Livestock Science 111(12): 45-56.

54. AHDB (Agriculture and Horticulture Development Board) (2013) The effect of reducing dietary crude protein on nitrogen utilisation, milk production, health and fertility in dairy cows. Report prepared by University of Nottingham and Harper Adams University on behalf of Dairy Co, Uk.

55. Funston R (2014) Importance of early conception and factors influencing it: Proceedings, The State of Beef Conference November 4 and 5, 2014, North Platte, Nebraska, USA.

56. Meza-Herrera CA, Ross TT, Hallford DM, Hawkins DE, Gonzalez-Bulnes A (2009) High pre-conceptional protein intake modifies uterine and embryonic relationships increasing early pregnancy losses and embryo growth retardation in sheep. Reprod Domest Anim 45(4): 723-728.

57. Bindari YR, Sulochana S, Nabaraj S, Tara NathGaire (2013) affects of nutrition on reproduction- A review. Advances in Applied Science Research 4(1): 421-429.

58. Thatcher WW, Guzeloglu A, Mattos R, Binelli M, Hansen TR, et al. (2001) Uterine-conceptus interactions and reproductive failure in cattle. Theriogenology 56(9): 1435-1450.

59. Chapa AM, McCormick ME, Fernandez JM, French DD, Ward JD, et al. (2001) Supplemental dietary protein for grazing dairy cows: reproduction, condition loss, plasma metabolites, and insulin. J Dairy Sci 84(4): 908-916.

60. Waterman RC, Sawyer JE, Mathis CP, Hawkins DE, Donart GB, et al. (2006) Effects of supplements that contain increasing amounts of metabolizable protein with or without Ca-propionate salt on postpartum interval and nutrient partitioning in young beef cows. J Anim Sci 84(2): 433-446.

61. Endecott RL (2006) Nutrient partitioning in ruminants: Mechanisms and manipulation of acetate and glucose metabolism. PhD Diss, New Mexico State University, Las Cruces, USA.

62. Aboozar M, Amanlou H, Aghazadeh AM, Adl KN, Moeini MT, et al. (2012) Impacts of different levels of RUP on performance and reproduction of Holstein fresh cows. Journal of Animal and Veterinary Advances 11(9): 1338-1345.

63. Rochijan, Widyobroto BP, Ismaya (2016) Impact of high rumen undegraded protein (HRUP) supplementation to blood urea nitrogen and reproduction performance in early lactation dairy cows. Int J Dairy Sci 11(1): 28-34.

64. Rajala-Schultz PJ, Saville WJA, Frazer GS, Wittum TE (2001) Association between milk urea nitrogen and fertility in Ohio dairy cows. J Dairy Sci 84(2): 482-489.

65. Sawa A, Bogucki M, Krężel-Czopek S (2011) Effect of some factors on relationships between milk urea levels and cow fertility. ArchivTierzucht 54(5): 468-476.

66. Jankowska M, Sawa A, Neja W (2010) Effect of milk urea and protein levels on fertility indices in cows. J Central European Agriculture 11(4): 476-479.

67. Řehák D, Rajmon R, Kubešová M, Štípková M, Volek J, et al. (2009) Relationships between milk urea and production and fertility traits 
in Holstein dairy herds in the Czech Republic. Czech J Anim Sci 54(5): 193-200.

68. Alonso L, Maquivar M, Galina CS, Mendoza GD, Guzman A, et al. (2008) Effect of ruminally protected methionine on the productive and reproductive performance of grazing Bosindicus heifers raised in the humid tropics of Costa Rica. Trop Anim Health Prod 40(8): 667-672.

69. Ardalan M, Rezayazdi K, Dehghan-Banadaky M (2010) Effect of rumenprotected choline and methionine on physiological and metabolic disorders and reproductive indices of dairy cows. J Anim Physiol Anim Nutr (Berl) 94(6): 259-265.

70. Sletmoen-Olson KE, Caton JS, Olson KC, Redmer DA, Kirsch JD, et al. (2000) Undegraded intake protein supplementation: II. Effects on plasma hormone and metabolite concentrations in periparturient beef cows fed low-quality hay during gestation and lactation. J Anim Sci 78(2): 456-463.

71. Kane KK, Creighton KW, Petersen MK, Hallford DM, Remmenga MD, et al. (2002) Effects of varying levels of undegradable intake protein on endocrine and metabolic function of young post-partum beef cows. Theriogenology 57(9): 2179-2191.

72. Hawkins DE, Petersen MK, Thomas MG, Sawyer JE, Waterman RC (2000) Can beef heifers and young postpartum cows be physiologically and nutritionally manipulated to optimize reproductive efficiency? Proc Am Soc Anim Sci.

73. Lalman DL, Petersen MK, Ansotegui RP, Tess MW, Clark CK, et al. (1993) The effects of ruminally undegradable protein, propionic acid, and monensin on puberty and pregnancy in beef heifers. J Anim Sci 71(11): 2843-2852.

74. Hammond AC (1992) Update on BUN and MUN as a guide for protein supplementation in cattle. $3^{\text {rd }}$ Annual Ruminant Nutrition Symposium. US Department of Agriculture, Agricultural Research Service, Subtropical Agricultural Research Station, Brooksville, Florida, pp. 34601-4672.

75. Tamminga S (2006) The effect of the supply of rumen degradable protein and metabolisable protein on negative energy balance and fertility in dairy cows. Anim Reprod Sci 96(3): 227-239.

76. Westwood CT, Lean IJ, Garvin JK, Wynn P (2000) Effects of genetic merit and varying dietary protein degradability on lactating dairy cows. J Dairy Sci 83(12): 2926-2940.

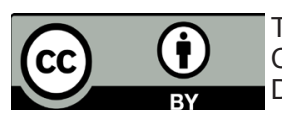

This work is licensed under Creative Commons Attribution 4.0 License DOI: 10.19080/JDVS.2018.05.555675
77. Ocon OM, Hansen PJ (2003) Disruption of bovine oocytes and pre implantation embryos by urea and acidic pH. J Dairy Sci 86(4): 11971200 .

78. Rhoads ML, Rhoads RP, Gilbert RO, Toole R, Butler WR (2006) Detrimental effects of high plasma urea nitrogen levels on viability of embryos from lactating dairy cows. Anim Reprod Sci 91(1-2): 1-10.

79. Sinclair KD, Kuran M, Gebbie FE, Webb R, McEvoy TG (2000) Nitrogen metabolism and fertility in cattle: II. Development of oocytes recovered from heifers offered diets differing in their rate of nitrogen release in the rumen. J Anim Sci 78(10): 2670-2680.

80. Leroy JLMR, Opsomer G, Van Soom A, Goovaerts IGF, Bols PEJ (2008) Reduced fertility in highyielding dairy cows: Are the oocyte and embryo in danger? Part I - The importance of negative energy balance and altered corpus luteum function to the reduction of oocyte and embryo quality in high-yielding dairy cows. Reprod Domest Anim 43(5): 612-622.

81. Wathes DC, Fenwick M, Cheng Z, Bourne N, Llewellyn S, et al. (2007) Influence of negative energy balance on cyclicity and fertility in the high producing dairy cow. Theriogenology 68(1): S232-S241.

82. Christensen RG (2015) Improvement of nutrient utilization efficiency, ruminal fermentation and lactational performance of dairy cows by feeding birdsfoot trefoil. All Graduate Theses and Dissertations p.4286.

83. De Boer IJM, Smits MCJ, Mollenhorst H, van Duinkerken G, Monteny GJ (2002) Prediction of ammonia emission from dairy barns using feed characteristics part I: relation between feed characteristics and urinary urea concentration. J Dairy Sci 85(12): 3382-3388.

84. Kebreab E, Strathe A, Fadel J, Moraes L, France J (2010) Impact of dietary manipulation on nutrient flows and greenhouse gas emissions in cattle. R Bras Zootec 39: 458-464.

85. Hristov AN, Heyler K, Schurman E, Griswold K, Topper P, et al. (2015) CASE STUDY: Reducing dietary protein decreased the ammonia emitting potential of manure from commercial dairy farms. The Professional Animal Scientist 31(1): 68-79.

86. Naves JR, de Jesus EF, Martins CMMR, Tomazi T, de Freitas JE, et al. (2015) Efficiency of dietary nitrogen utilization and digestivemetabolism of dairy cows fed different nitrogen sources and sugarcane. The Journal of Animal \& Plant Sciences 25(4): 941-949.

\section{Your next submission with Juniper Publishers will reach you the below assets}

- Quality Editorial service

- Swift Peer Review

- Reprints availability

- E-prints Service

- Manuscript Podcast for convenient understanding

- Global attainment for your research

- Manuscript accessibility in different formats

( Pdf, E-pub, Full Text, Audio)

- Unceasing customer service

Track the below URL for one-step submission https://juniperpublishers.com/online-submission.php 